\title{
Anti-CD19-DM4 Immunoconjugate SAR3419
}

National Cancer Institute

\section{Source}

National Cancer Institute. Anti-CD19-DM4 Immunoconjugate SAR3419. NCI Thesaurus.

Code C71009.

An immunoconjugate consisting of an anti-CD19 monoclonal antibody conjug ated to the maytansinoid DM4, a derivative of the cytotoxic agent maytansine (DM1), with potential antineoplastic activity. Anti-CD19-DM4 conjug ate SAR3419 targets the cell surface antigen CD19, found on a number of B-cell-derived cancers. Upon antibody/antigen binding and internalization, the immunoconjug ate releases DM4, which binds to tubulin and disrupts microtubule assembly/disassembly dynamics, resulting in inhibition of cell division and cell growth of CD19-expressing tumor cells. 